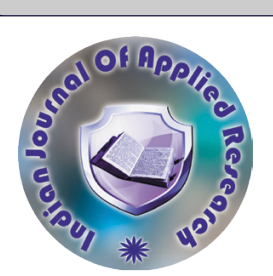

Endodontics

\title{
COMPARATIVE EVALUATION OF SEALING ABILITY OF DIFFERENT OBTURATION SYSTEMS: AN IN VITRO STUDY
}

\section{Deebah Choudhary*}

Senior Lecturer, Department Of Conservative Dentistry And Endodontics, Institute Of Dental Sciences, Sehora, Jammu, Jammu And Kashmir, India. ${ }^{*}$ Corresponding Author

ABSTRACT AIM: The aim of this study is to compare the sealing ability of three different obturation systems using a glucose penetration method. MATERIALS AND METHODS: A total of 60 extracted mandibular premolar with single root. The samples were decoronated. All the samples were instrumented and obturated with three different obturation techniques i.e. Cold lateral compaction, GuttaFlow2 and Thermafil. After 1 week, the sealing ability of the obturated root canals were tested at different time intervals using glucose penetration test. A spectrophotometer was used to measure glucose leakage. Statistical analysis was done using Kruskal Wallis test. RESULTS: The three groups showed significantly different glucose leakage values at different time intervals $(\mathrm{P}<0.05)$. The glucose leakage was maximum for Group I (Cold Lateral Condensation) as compared to Group II and Group III (GuttaFlow2 and Thermafil). CONCLUSION: Thermafil system of obturation provided the superior sealing ability over GuttaFlow2 and lateral compaction technique.

\section{KEYWORDS : Thermafil; Sealing Ability; Guttaflow2; Obturation; Cold Lateral Compaction}

\section{INTRODUCTION:}

Root canal obturation aims at filling the material into all spaces of the canal and also seal the entry portals between the periodontium ad the canal ${ }^{1}$. It has been reported that $58 \%$ of endodontic treatment fails due to improper root canal obturation ${ }^{2}$. Various studies reveals that failed obturation leads to high rate of periapical lesion in the teeth ${ }^{3.5}$. A fluidtight seal is achieved when Gutta-percha is used with sealers ${ }^{6}$.

In order to achieve a good marginal seal of the root canal, new obturation systems are being developed which improves efficacy of the dentist and is less stressful for the patients. It is revealed that guttapercha is not ideal filling material for the root canal filling but it has properties like reduced tissue irritability, minimal toxicity and allergenicity, makes it a most popularly used endodontic material ${ }^{7}$. The drawback of gutta-percha is that it lacks adhesiveness to itself and to the canal walls, due to this reason it has to be used with a sealer or cement. Microleakage between the gutta-percha and the sealer causes endodontic failure. Microleakage in endodontically obturated canal is a complicated process that can understood as the passage of bacteria, fluids and chemical substances between the spaces in the root canal ${ }^{8}$.

To evaluate the sealability of root canal filling materials and techniques, various methods are being advocated which uses a tracer that penetrate along the filling materials. These tracers are mainly dyes, bacteria, radioisotopes and liposaccharides ${ }^{9}$. Another method which has been in use now-a-days is glucose penetration test which determines the amount of glucose that be enforced under hydrostatic pressure using an enzyme detection method ${ }^{10}$. Under ideal conditions in in-vitro studies shows that no canal filling material/technique can achieve a long-term success as an idea obturation material.

Research database available, states that very less studies has been conducted to determine the sealing ability of new obturation materials. Hence, the aim of the present study is to compare the sealing ability of three different root canal filling systems i.e. Cold lateral condensation technique, GuttaFlow2 and Thermafil, using glucose penetration test.

\footnotetext{
Material and Methods:

Sample preparation

A total of sixty extracted human mandibular premolars having mature single root were selected for the study. The teeth were extracted due to orthodontic purposes. Only those teeth were selected which were free of caries, cracks, curvatures and fractures. The selected teeth were stored in normal saline solution until use. The samples were decoronated with slow speed diamond disk attached to micromotor under copious amount of water leaving $15 \mathrm{~mm}$ of root length. Canal patency was obtained using 10K file (Dentsply Maillefer, Ballaigues, Switzerland) and working length was determined by $15 \mathrm{~K}$ file (Dentsply Maillefer, Ballaigues, Switzerland) under a radiograph. The canals of all the samples were prepared by rotary ProTaper files (Dentsply Maillefer, Ballaigues, Switzerland) till F3 file apically. After
}

the completion of the preparation the canals were thoroughly flushed with $5 \mathrm{ml}$ of $17 \%$ EDTA solution followed by final rinse with $\mathrm{NaOCl}$.

\section{Samples Grouping and Obturation}

Before canals were obturated the samples were dried with corresponding paper point F3 (Dentsply Maillefer, Ballaigues, Switzerland). The root canals were filled in following way:

Group I (Cold Lateral Condensation technique) $(\mathbf{n}=20)$. A standardized gutta-percha master cone was selected and inserted till working length. A slight "tug back" was felt on its withdrawal. AH-26 sealer was applied to the master cone and obturation was carried out by placing accessory cone with help of a spreader.

\section{Group II (GuttaFlow2) $(\mathrm{n}=\mathbf{2 0})$.}

Master cone was selected and coated with GuttaFlow. It was placed in the canal and accessory cones were placed to back fill the canal along with GuttaFlow.

\section{Group III (Thermafil) $(\mathbf{n}=\mathbf{2 0})$.}

A Thermafil obturator was selected. Rubber stopper was adjusted on the obturator with help of calibrations on the carrier. The thermaprep was heated for 15 seconds with obturator. AH-26 sealer was placed in the canal and obturator was inserted till working length and stabilized with firm post pressure. The shaft was sheared-off at the orifice.

The teeth orifices were sealed by temporary restoration Cavit. All samples were incubated at $37^{\circ} \mathrm{C}$ for 1 week in $95 \%$ humidity to allow complete setting of sealers.

\section{Apical Microleakage measurement}

Following obturation, the surfaces of the root of all the samples were coated with two coats of nail paint leaving apical $1 \mathrm{~mm}$ of root end. Microleakage was evaluated using glucose leakage mode ${ }^{10}$. Leaked concentrations of glucose were measured at intervals after 1 day, 1 week, 3 weeks and 6 weeks with a Glucose kit (Glucose Liquid, Quimica Clinica Applicada S.A) in a spectrophotometer (Shimadzu UV 1800) at wave length of $505 \mathrm{~nm}$.

\section{Statistical Analysis}

The results were statistically analyzed by Kruskal-Wallis using SPSS program version 21.0 (SPSS Inc., Chicago, IL, USA). All level of statistical significance was set at a $P$ value less than 0.05 .

\section{Results:}

The results of present study determined that during the experiment, an increase was observed in the glucose leakage in the filling of the teeth from three study groups. Among the three obturation systems evaluated in the study, the highest glucose concentration was observed in samples obturated with cold lateral compaction. After first day onwards, there were significant differences between the experimental groups (Kruskal Wallis test, $\mathrm{P}<0.05$ ) [Figure 1]. 
Glucose leakage mean value comprisionat different time intervals

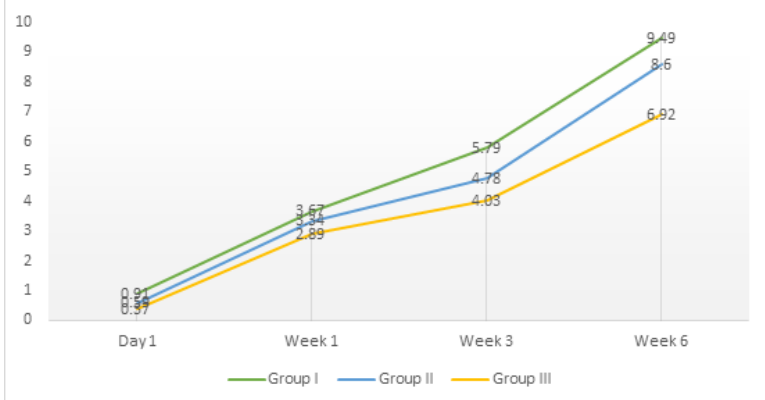

Figure 1: Rate of Glucose leakage $(\mathrm{mg} / \mathrm{dL})$ within experimental groups over different time intervals

The mean values and statistical comparisons between the three groups at each time indicated that there was significant difference between the three groups at different time periods. Group I showed maximum glucose leakage as compared to Group II and Group III [Table 1].

Table 1: Comparison of glucose leakage mean values $(\mathrm{mg} / \mathrm{dL})$ in the experimental groups at different time intervals after obturation

\begin{tabular}{|c|c|c|c|c|}
\hline \multirow{2}{*}{ Groups } & \multicolumn{4}{|c|}{$\begin{array}{c}\text { Glucose concentration mg/dL } \\
\text { (Mean Standard deviation) }\end{array}$} \\
\cline { 2 - 5 } & 1 Day & 1 Week & 3 Weeks & 6 Weeks \\
\hline $\begin{array}{c}\text { Group I (Cold } \\
\text { Lateral } \\
\text { Compaction) }\end{array}$ & 0.910 .139 & 3.671 .04 & 5.791 .87 & 9.490 .97 \\
\hline $\begin{array}{c}\text { Group II } \\
\text { (GuttaFlow2) }\end{array}$ & 0.590 .082 & 3.341 .00 & 4.781 .65 & 8.601 .62 \\
\hline $\begin{array}{c}\text { Group III } \\
\text { (Thermafil) }\end{array}$ & 0.370 .041 & 2.890 .76 & 4.031 .11 & 6.921 .54 \\
\hline $\begin{array}{c}\text { Kruskal-Wallis } \\
\text { Test (P) }\end{array}$ & $0.000^{*}$ & $0.0479^{*}$ & $0.0048^{*}$ & $0.000^{*}$ \\
\hline
\end{tabular}

${ }^{*} \mathrm{P}<0.05$ indicates statistically significant difference between groups

\section{DISCUSSION:}

The sealing ability of root canal filling material has been evaluated, mostly by in vitro studies. In vitro approaches is used when a material is impossible to be evaluated in clinical conditions. In order to get a correct result from in vitro studies, proper clinical situation must be reproduced $^{11}$. The glucose leakage has been widely used method to evaluate the quality of filling material ${ }^{10}$. Glucose has advantage being hydrophilic, it can penetrate the spaces available due to low molecular weight. Also the amount of bacterial present is directly proportional to the sugar available, as bacteria feeds on glucose $\mathrm{e}^{10}$. Moreover, the glucose can't show a false positive result as the solution cannot penetrate through the dentin of the root ${ }^{12}$.

Various materials have been used for the purpose of obturation. From many years gutta-percha has been used as an obturation material in endodontically treated teeth. It cannot be considered as ideal obturation material but it satisfies majority of Grossman's criteria. The most widely used method for obturation with gutta-percha is lateral compaction $^{13}$. It is most used as a gold standard for evaluating sealing ability of new obturation methods. The major disadvantages of this kind of obturation technique is that it lacks adaptation to canal walls and also show large number of voids ${ }^{13}$.

Another material which applies thermoplastic method of obturation is Thermafil (Dentsply Tulsa Dental) which is a soil core gutta-percha. It has the advantages of easy placement due to rigid central core ${ }^{14}$. GuttaFlow is another material used in the study which is a modification of RoekoSeal Automix and provides a consistent seal of about 18 months ${ }^{15}$. It consists of small gutta-percha particles $(30 \mathrm{~m})$ mixed with a sealer mixed in its mass. It has a good adaptability to root canal walls and expands on setting, thus showing a better sea $1^{16}$.

In this study, a slow gradual increase in glucose was observed over different time intervals. Samples obturated with Thermafil showed least amount of leakage, this may be attributed to the reduced shrinkage of gutta-percha which prevents setting contraction ${ }^{17}$. Also, the thermoplasticized gutta-percha flow into the patent dentinal tubules. All these factors contribute to the enhanced sealing ability of Thermafil.

The results of this study is quite similar to a study conducted which concluded that GttaFlow shows more microleakage than Thermafil ${ }^{18}$. Although, GuttaFlow is said to expand on setting but it shows large number of voids and gaps ${ }^{19}$. Moreover due to lack of heat, there is no chemical union between particles of GuttaFlow and master cone guttapercha ${ }^{20}$. A study conducted by Priyank et $\mathrm{al}^{21}$ contrasting result from this study which concluded that Thermafil obturation showed maximum microleakage followed by GuttaFlow and cold lateral condensation.

\section{CONCLUSION:}

Within the limitation of this study the flowing conclusions could be drawn:

1. All the three groups showed some kind of microleakage, thus none of method shows a fluid-tight sealing ability.

2. There is progressive increase in the glucose leakage value over time for all the groups.

3. Root canals obturated by Thermafil system revealed least glucose penetration as compared to GuttaFlow2 and Cold lateral compaction

\section{REFERENCES:}

1. Keçeci AD, Unal GC, Sen BH. Comparison of cold lateral compaction and continuous wave of obturation techniques following manual or rotary instrumentation. Int Endod J 2005;38:381-8.

2. Ingle JI, Beveridge E, Glick D, Weichman J: The Washington study. In: Ingle I, Taintor JF, editors. Endodontic. Philadelphia: Lea \& Febiger; 1994. p. 1-53.

3. Boucher Y, Matossian L, Rilliard F, Machtou P. Radiographic evaluation of the prevalence and technical quality of root canal treatment in a French subpopulation. Int Endod J 2002;35:229-238.

4. Kirkevang LL, Hørsted-Bindslev P. Technical aspects of treatment in relation to treatment outcome. Endod Top 2002;2:89-102.

5. Segura-Egea JJ, Jiménez-Pinzón A, Poyato-Ferrera M, Velasco-Ortega E, Ríos-Santos JV. Periapical status and quality of root fillings and coronal restorations in an adult Spanish population. Int Endod J 2004;37:525-5

6. Sönmez IS, Oba AA, Sönmez D, Almaz ME. In vitro evaluation of apical microleakage of a new MTA-based sealer. Eur Arch Paediatr Dent 2012;13:252-255.

7. Ørstavik D. Materials used for root canal obturation: technical, biological and clinical testing. Endod Top 2005;12:25.

8. Zhang W, Zhi L, Peng B, Wuhan C. Assessment of a new root canal sealer's apical sealing ability. Oral Surg Oral Med Oral Pathol Oral Radiol Endod 2009; 107:e79-e82.

9. Li GH, Niu LN, Zhang W, et al. Ability of new obturation materials to improve the seal of the root canal system: a review. Acta Biomater. 2014;10(3):1050-1063.

10. Xu Q, Fan MW, Fan B, Cheung GS, Hu HL. Anew quantitative method using glucose for analysis of endodontic leakage. Oral Surg Oral Med Oral Pathol Oral Radiol Endod 2005;99:107-11.

11. G. DeDeus, "New directions in old leakage methods," International Endodontic Journal, vol. 41, no. 8, pp. 720-721,2008.

12. Shemesh $H$, van den Bos M, Wu MK, Wesselink PR. Glucose penetration and fluid transport through coronal root structure and filled root canals. Int Endod J. 2007;40(11):866-872.

13. Dalat DM, Spångberg LS. Comparision of apical leakage in root canals obturated with various gutta percha techniques using a dye vacuum tracing method. J Endod. 1994;20:315-9

14. Punia SK, Nadig P, Punia V. An in vitro assessment of apical microleakage in root canals obturated with gutta-flow, resilon, thermafil and lateral condensation: A stereomicroscopic study. J Conserv Dent. 2011;14(2):173-177.

15. Kontakiotis EG, Tzanetakis GN, Loizides AL. A 12-month longitudinal in vitro leakage study on a new silicon-based root canal filling material (Gutta-Flow). Oral Surg Oral Med Oral Pathol Oral Radiol Endod 2007;103(6):854-

16. Elayouti A, Achleithner C, Löst C, Weiger R. Homogenicity and adaptation of new gutta percha paste to root canal walls. J Endod. 2005;31:687-90.

17. Clark.D.S and Eldeeb M.E Apical sealing ability metal versus plastic Thermafil obturators. J.Endod 1993;19:4-9.

18. Rajkumar B, Shukla P, Popli G, Gupta V, Bhatt A. Comparative evaluation of apical microleakage of three different obturating material using stereomicroscopy. Int J Adv Multidiscip Res. 2016;3(6):1-4

19. Ravanshad $\mathrm{S}$ and Torabinejad $\mathrm{M}$. Coronal dye penetration of the apical filling materials after post space preparation. Oral Surg Oral Med Oral Pathol 1992;74:644-647.

20. Monticelli F, Sword J, Martin RL, Schuster GS, Weller RN, Ferrari M, Pashley DH, Tay FR Sealing properties of two contemporary single-cone obturation systems. IntEndod J. 2007;40(5):374-85.

21. Priyank H, V. Mahalakshmi, Verma A. Comparative Analysis on Apical Microleakage in Root Canals Obturated with Gutta flow, Thermafil and Regular Guttapercha with Latera Condensation-A Stereomicroscopic Study. J Adv Med Dent Scie Res 2017;5(10): 1-6. 